\title{
Career Choices among Nursing Students: Differences Between Freshmen and Interns
}

\author{
Ni Putu Wulan Purnama Sari
}

Department of Palliative Nursing, Faculty of Nursing, Widya Mandala Catholic University Surabaya, Surabaya, Indonesia

Corresponding Email: wulanpurnama@ukwms.ac.id

\section{ARTICLE INFO \\ HOW TO CITED: \\ Sari, N.P.W. (2020). Career Choices among Nursing Students: Differences Between Freshmen and Interns. Jurnal Pendidikan Keperawatan Indonesia 6(1), p. 1-13}

DOI:

10.17509/jpki.v6i1.18758

ARTICLE HISTORY:

Received

July 29, 2019

Revised

December 11, 2019

Accepted

March 19, 2020

Published

June 20, 2020

\section{ABSTRACT}

Career selection is one of the most important decisions that an individual makes in his life and is a core task of the late stages of adolescent development in the process of developing self-identity. This study aimed to describe the career choices of nursing students and analyze the differences between freshmen and interns. This cross-sectional study involved 110 and 66 freshmen and interns respectively in two private nursing colleges with "B" accreditation predicate $(n=176)$. Questionnaire of Survey on Career Choice was used in data collection. Descriptive statistic test was used in data analysis. Results showed that most freshmen chose two career choice alternatives $(38.18 \%)$, but most interns were determined to choose only one alternative $(42.42 \%)$. There were two most popular career choices among nursing students, such as: nurse practitioner ( $45.45 \%$ totally) and continuing education to be a Master/Specialist of Nursing (33.52\% totally). The career intention to be a nurse practitioner in most respondents was referred to civil servant, both in clinical or community work places (59.66\% totally). The most popular nursing fields were pediatric nursing in freshmen and psychiatric nursing in interns $(34.55 \%$ and $25.76 \%$ respectively). Strengthening the attitude of love for nursing profession needs to be fostered early in the beginning of college life, so that career choice as a nurse practitioner after finishing the internship program can be maintained.

Keywords: career choice, nurse, nursing student.

\begin{abstract}
ABSTRAK
Pemilihan karir adalah salah satu keputusan terpenting yang dibuat individu dalam hidupnya dan merupakan tugas inti dari tahap perkembangan remaja akhir dalam proses pembangunan identitas diri. Penelitian ini bertujuan mendeskripsikan pilihan karir mahasiswa keperawatan dan menganalisis perbedaannya di antara mahasiswa baru dan program Profesi Ners. Penelitian cross-sectional ini melibatkan 110 maba dan 66 mahasiswa profesi yang berasal dari dua institusi keperawatan terakreditasi $B(n=176)$. Kuesioner Survey on Career Choice digunakan dalam pengumpulan data. Uji statistika deskriptif digunakan untuk menganalisis data. Hasil menunjukkan mayoritas maba memilih dua alternatif pilihan karir (38.18\%), sedangkan mahasiswa profesi Ners mantap memilih satu pilihan saja (42.42\%). Terdapat dua jenis pilihan karir yang populer pada mahasiswa keperawatan, yaitu sebagai perawat praktisi (total 45.45\%) dan studi lanjut untuk menjadi Magister/Spesialis Keperawatan (total 33.52\%). Intensi karir sebagai perawat praktisi pada mayoritas responden mengarah pada menjadi Pegawai Negeri Sipil (PNS), baik di tatanan klinik maupun komunitas (total 59.66\%). Bidang Keperawatan Anak paling populer di kalangan maba (34.55\%), sedangkan bidang Keperawatan Jiwa paling populer di kalangan mahasiswa Profesi Ners (25.76\%). Penguatan sikap kecintaan terhadap profesi perawat perlu dipupuk sejak dini di awal masa kuliah agar pilihan karir sebagai perawat praktisi pasca lulus dari program Profesi Ners dapat dipertahankan.
\end{abstract}

Kata kunci: mahasiswa keperawatan, perawat, pilihan karir. 
Sari, N.P.W. | Career Choices among Nursing Students: Differences Between Freshmen ...

\section{INTRODUCTION}

Career is a lifestyle concept that includes tiered work activities throughout life. Careers also include activities before and after getting skills and decisions about how a person brings his work life together into other life roles (Schutt, 2008). Career selection is one of the most important decisions an individual makes in his life. Career choice is seen as a core task of the late stages of adolescent development in the process of developing selfidentity (Kunnen, 2013). A career that has been chosen has a major contribution to the lives of individuals and can be at the core of one's basic values and life goals.

The decline in the number of nurses that occur today and continues to occur in the last few decades in various countries has become a global problem (WHO, 2006). Previous studies have shown that despite the fact that there is a downward trend in the number of nurses in various parts of the world, it turns out that not many millennial are interested in cultivating the nurse profession (Diomidous, 2012). In Indonesian context, nurse surplus coexists with nurse shortage leading to unequal distribution of nurses in the country and emerging the needs of nurse migration (Gunawan \& Aungsuroch, 2015). The growth and resilience of the nursing profession depends on the ability to recruit and retent the next generation of professional nurses (Price, 2011). Therefore, if the career choice to become a nurse practitioner is the last thing comes to mind in the head of our nursing students nowadays when we discuss about their prospected profession after graduation then it means that Indonesian Nurses Association and generally the government in health sector will face real great problems in the future due to the nursing shortage condition. Understanding millennial generation career choices is a critical component of nurse recruitment and retention strategies (Bloomberg, 2011; in Price, 2011).

Career choice is seen as a complex consideration of social position, full of hopes, dreams, doubts, and personal tensions. Students' perceptions and expectations relating to their career as a nurse in the future are influenced by historical understanding and stereotypes of nursing profession itself; an image that often exists in the community (Price, 2011). The students' motives for selecting a career are influenced by personal cognitive factors, such as: self-realization, the need for autonomy, social status, personal or financial development (Haase, 2011). So far in Indonesia, there are four alternatives of career choices for nursing students, namely: educator, researcher, nurse practitioner, and community nurse (Magno, 2017). Some criteria that are often used by nursing students before choosing to be a nurse practitioner include: 1) feeling happy to care for sick people, 2) being considered as health professionals, 3 ) easy to get a job, 4) match to the personality type, 5) considered as important profession for the community, 6) willing to help shaping the nursing profession, 7) have the potential to get a high salary, 8) influence from family and friends, and 9) there are health problems in the family (Diomidous, 2012). A comparative study between freshmen and pre-graduated nursing students in Sweden showed that there were three factors incorporating $50-60 \%$ variances of students' motives for becoming a nurse, such as: genuine interest, practical reasons, and default choice (Jirwe \& Rudman, 2012).

Today there are many career choices that can be offered to nursing graduates, especially Bachelor of Nursing, or nursing undergraduates. With more promising reward promotions, higher salary or bonus, insurance, etc., from the employer agencies, it is not uncommon for nursing graduates to prefer other professions, for example: working in beauty clinics, health insurance companies, banks, being entrepreneurs, lecturers, researchers, personal assistants, or others. Reality in the field, generally found mostly in sub-urban or rural areas, the salary of nurse practitioner is still below the minimum wage of the city. When compared with the tuition spent to become a Bachelor of Nursing and the effort that has been made to be able to finish the study on time, this is felt by some individuals to be truly incomparable. In addition, there are still limited employment opportunities for Bachelor of Nursing in several locations because 
Sari, N.P.W. | Career Choices among Nursing Students: Differences Between Freshmen ...

the employers prefer to employ graduates of nursing diploma for reasons of being more skilled and lower salary standards. Other obstacles found in the field are also related to the future career ladder which is less noticed by the authority manager because some hospitals do not have any mature career ladder system with clear credentialing criteria yet.

By knowing these various situations existed in the field, most nursing students are aware to think and decide carefully about their future career choices. This study aimed to describe the career choices of nursing students and analyze the differences between $1^{\text {st }}$ year nursing students (freshmen) and interns ( $5^{\text {th }}$ year nursing students). In Indonesian nursing education system, especially for Bachelor of Nursing, the study periods are divided into two terms, such as: four years study in the university to get the title of Bachelor of Nursing, and one additional year of internship period in the field as a requirement of pursuing the national licensure examination (not always compulsory). By knowing this study results, it will be beneficial for: 1) the nursing institution to develop certain program to increase students' interest towards nursing profession, 2) the government and employer agencies to develop various recruitment strategies or interventions in order to increase the number of nurses in the future.

\section{METHOD}

This cross-sectional study involved 110 nursing freshmen and 66 nursing interns in two private nursing colleges in the middle part of Indonesia, both institutions were "B" accredited. Inclusion criteria were freshmen or intern aged at least 16 years old and being an active student in the commencement of even semester, academic year of 2018/2019. Exclusion criteria were rejection on filling out the consent form, and late submission of questionnaire. Total sampling was applied and sample size of 176 was obtained. Data were collected since February until March, 2019, in both sites. Ethical clearance was issued by Faculty of Medicine, Widya Mandala Catholic University
Surabaya, Indonesia, with certificate number of 009/WM12/KEPK/T/2019.

Questionnaire of Survey on Career Choice was used in data collection. This instrument was developed by Takeda, et al. (2013), which initially being used on career survey of medical students in Japan. Researcher then modify this instrument to make it suitable for usage in nursing students. This questionnaire has three parts, such as: 1) basic information (part I: Q1-8), 2) future career plan and nursing field of interest wanted to pursue (part II: Q9-12, Q12 has 31 items), and 3) future career plan and work place (part III: Q13-14, Q13 has 20 items). Totally, there are 67 items divided in three parts, in which 4 items are questions about demographic (which was excluded because the researcher has developed a demographic questionnaire herself), therefore there were 63 items. Instrument testing procedure was only done for Q12 and Q13 with Likert scale format (score 14). Results showed that after a testing procedure towards 18 nursing students, Q12 has 14 valid items $(\mathrm{r}=0.492-0.754$, Chronbach Alpha $=$ 0.902 ), and after a testing procedure towards 23 nursing students, Q13 has 14 valid items too $(\mathrm{r}=$ 0.428 - 0.860, Chronbach Alpha $=0.901$ ). Descriptive statistic test was used in data analysis.

\section{RESULTS}

The majority was female aged 18-20 years old, Balinese, living with parents whose profession was other than health professional. Table 1 explains the demography characteristic of study respondents in details.

Most respondents were introverted individuals, tending to be melancholic, with realistic characters. In their daily lives, they mostly hang out with peers who both are nursing students, and one of their closest person is a nurse. The majority respondents chose nursing major at their own discretion because it had become their dream since childhood, most claimed have no specific role model. Parents are the parties who provide the greatest motivation to most respondents. Most claimed to have never attended other majors, did not have previous degrees outside the Nursing / 
Sari, N.P.W. | Career Choices among Nursing Students: Differences Between Freshmen ...

Nurse Bachelor, and had never worked. Table 2 explains the specific characteristic of study respondents in details.

Results showed that most freshmen chose two career choice alternatives $(38.18 \%)$, but most interns were determined to choose only one alternative $(42.42 \%)$. There were two most popular career choices among nursing students, such as: nurse practitioner ( $45.45 \%$ totally) and continuing education to be a Master/Specialist of Nursing ( $33.52 \%$ totally). The career intention to be a nurse practitioner in most respondents was referred to civil servant, both in clinical or community work places $(59.66 \%$ totally). Most respondents were unable to decide the type of nursing practitioner they wanted to be in the future ( $44.89 \%$ totally). The most popular nursing fields were pediatric nursing in freshmen and psychiatric nursing in interns (34.55\% and $25.76 \%$ respectively). In $2^{\text {nd }}$ place, the fields of surgical and emergency nursing were the two fields which similarly popular in nursing students. Table 3 explains comparison of career choices between nursing freshmen and interns in details.

Table 1. Demography characteristic

\begin{tabular}{|c|c|c|c|c|}
\hline \multirow{2}{*}{ CHARACTERISTIC } & \multicolumn{2}{|c|}{ FRESHMEN $(n=110)$} & \multicolumn{2}{|c|}{ INTERN $(\mathrm{n}=66)$} \\
\hline & FREQUENCY & $\%$ & FREQUENCY & $\%$ \\
\hline \multicolumn{5}{|l|}{ 1. Age (years old) } \\
\hline a. $16-17$ & 14 & 12.73 & 0 & 0 \\
\hline b. $18-20$ & 90 & 81.82 & 1 & 1.52 \\
\hline c. $21-23$ & 5 & 4.55 & 58 & 87.88 \\
\hline d. $24-26$ & 0 & 0 & 7 & 10.61 \\
\hline e. $>26$ & 1 & 0.91 & 0 & 0 \\
\hline \multicolumn{5}{|l|}{ 2. Gender } \\
\hline a. Female & 85 & 77.27 & 49 & 74.24 \\
\hline b. Male & 25 & 22.73 & 17 & 25.76 \\
\hline \multicolumn{5}{|l|}{ 3. Sub-ethnic } \\
\hline a. Javanese & 18 & 16.36 & 10 & 15.15 \\
\hline b. Balinese & 58 & 52.73 & 47 & 71.21 \\
\hline c. Chinese & 2 & 1.82 & 1 & 1.52 \\
\hline d. NTT or east Indonesia & 18 & 16.36 & 5 & 7.58 \\
\hline e. Borneo & 3 & 2.73 & 0 & 0 \\
\hline f. Sulawesi & 0 & 0 & 2 & 3.03 \\
\hline g. Others & 11 & 10.00 & 1 & 1.52 \\
\hline \multicolumn{5}{|l|}{ 4. Living at home with } \\
\hline a. Parents & 59 & 53.64 & 52 & 78.79 \\
\hline b. Sibling & 4 & 3.64 & 2 & 3.03 \\
\hline c. Extended Family & 13 & 11.82 & 6 & 9.09 \\
\hline d. Friends & 30 & 27.27 & 5 & 7.58 \\
\hline e. Alone & 4 & 3.64 & 1 & 1.52 \\
\hline \multicolumn{5}{|l|}{ 5. Nurse is parent's profession } \\
\hline a. Yes & 6 & 5.45 & 4 & 6.06 \\
\hline b. No & 104 & 94.55 & 62 & 93.94 \\
\hline
\end{tabular}


Sari, N.P.W. | Career Choices among Nursing Students: Differences Between Freshmen ...

Table 2. Specific characteristic

\begin{tabular}{|c|c|c|c|c|}
\hline \multirow{2}{*}{ CHARACTERISTIC } & \multicolumn{2}{|c|}{ FRESHMEN $(\mathbf{n}=110)$} & \multicolumn{2}{|c|}{ INTERN $(n=66)$} \\
\hline & FREQUENCY & $\%$ & FREQUENCY & $\%$ \\
\hline \multicolumn{5}{|l|}{ 1. General personality } \\
\hline a. Introvert & 52 & 47.27 & 41 & 62.12 \\
\hline b. Extrovert & 58 & 52.73 & 25 & 37.88 \\
\hline \multicolumn{5}{|l|}{ 2. Personality type } \\
\hline a. Sanguine & 36 & 32.73 & 10 & 15.15 \\
\hline b. Melancholic & 53 & 48.18 & 41 & 62.12 \\
\hline c. Choleric & 11 & 10.00 & 12 & 18.18 \\
\hline d. Phlegmatic & 10 & 9.09 & 3 & 4.55 \\
\hline \multicolumn{5}{|l|}{ 3. Character } \\
\hline a. Realistic & 67 & 60.91 & 53 & 80.30 \\
\hline b. Investigative & 10 & 9.09 & 2 & 3.03 \\
\hline c. Artistic & 9 & 8.18 & 6 & 9.09 \\
\hline d. Social & 17 & 15.45 & 5 & 7.58 \\
\hline e. Entrepreneur & 7 & 6.36 & 0 & 0 \\
\hline \multicolumn{5}{|l|}{ 4. Daily association (friendship) } \\
\hline a. Family & 3 & 2.73 & 6 & 9.09 \\
\hline b. Friends & 107 & 97.27 & 59 & 89.39 \\
\hline c. Partner & 0 & 0 & 0 & 0 \\
\hline d. Professionals & 0 & 0 & 1 & 1.52 \\
\hline \multicolumn{5}{|l|}{ 5. Profession of people in daily association } \\
\hline a. Nurse & 4 & 3.64 & 11 & 16.67 \\
\hline b. Doctor & 0 & 0 & 1 & 1.52 \\
\hline e. Others & 106 & 96.36 & 54 & 81.82 \\
\hline \multicolumn{5}{|l|}{ 6. Profession of house-mate } \\
\hline a. Nurse & 3 & 2.73 & 4 & 6.06 \\
\hline b. Doctor & 1 & 0.91 & 1 & 1.52 \\
\hline c. Pharmacist & 1 & 0.91 & 0 & 0 \\
\hline d. Others & 105 & 95.45 & 61 & 92.42 \\
\hline \multicolumn{5}{|l|}{ 7. Close person is a nurse } \\
\hline a. Yes & 74 & 67.27 & 32 & 48.48 \\
\hline b. No & 36 & 32.73 & 34 & 51.52 \\
\hline \multicolumn{5}{|l|}{ 8. Reason of choosing nursing major } \\
\hline a. Making family proud & 1 & 0.91 & 0 & 0 \\
\hline b. Being able to care the family & 9 & 8.18 & 6 & 9.09 \\
\hline c. Childhood dream & 54 & 49.09 & 13 & 19.70 \\
\hline d. Being able to help others & 32 & 29.09 & 14 & 21.21 \\
\hline e. Many job opportunities & 3 & 2.73 & 8 & 12.12 \\
\hline f. Others (significant others influences) & 11 & 10.00 & 25 & 37.88 \\
\hline \multicolumn{5}{|l|}{ 9. Motivator } \\
\hline a. Parents & 90 & 81.82 & 54 & 81.82 \\
\hline b. Self & 18 & 16.36 & 10 & 15.15 \\
\hline c. Others & 2 & 1.82 & 2 & 3.03 \\
\hline \multicolumn{5}{|l|}{ 10. Role model } \\
\hline a. Parents & 39 & 35.45 & 27 & 40.91 \\
\hline b. Lecturer/Teacher & 4 & 3.64 & 1 & 1.52 \\
\hline c. Sibling & 5 & 4.55 & 0 & 0 \\
\hline d. Public figure & 5 & 4.55 & 6 & 9.09 \\
\hline e. Others & 12 & 10.91 & 3 & 4.55 \\
\hline f. None & 45 & 40.91 & 29 & 43.94 \\
\hline \multicolumn{5}{|l|}{ 11. Role model is a nurse } \\
\hline a. Yes & 60 & 54.55 & 20 & 30.30 \\
\hline b. No & 50 & 45.45 & 46 & 69.70 \\
\hline \multicolumn{5}{|l|}{ 12. Experience of choosing other major } \\
\hline a. Yes & 19 & 17.27 & 11 & 16.67 \\
\hline b. No & 91 & 82.73 & 55 & 83.33 \\
\hline 13. Having degree in other major & & & & \\
\hline a. Yes & 7 & 6.36 & 4 & 6.06 \\
\hline b. No & 103 & 93.64 & 62 & 93.94 \\
\hline 14. Experience of working & & & & \\
\hline a. Yes & 17 & 15.45 & 6 & 9.09 \\
\hline b. No & 93 & 84.55 & 60 & 90.91 \\
\hline
\end{tabular}


Sari, N.P.W. | Career Choices among Nursing Students: Differences Between Freshmen ...

Table 3. Comparison of career choices between nursing freshmen and interns in details

\begin{tabular}{|c|c|c|c|c|}
\hline \multirow{2}{*}{ CHARACTERISTIC } & \multicolumn{2}{|c|}{ FRESHMEN (n=110) } & \multicolumn{2}{|c|}{ INTERN $(n=66)$} \\
\hline & FREQUENCY & $\%$ & FREQUENCY & $\%$ \\
\hline \multicolumn{5}{|l|}{ 1. Career intention after graduation } \\
\hline a. Master of Nursing & 26 & 23.64 & 7 & 10.61 \\
\hline b. Specialist of Nursing & 15 & 13.64 & 11 & 16.67 \\
\hline c. Nursing practitioner & 54 & 49.09 & 26 & 39.39 \\
\hline d. Nursing lecturer & 5 & 4.55 & 3 & 4.55 \\
\hline e. Entrepreneur & 1 & 0.91 & 0 & 0 \\
\hline f. Study master (others) & 0 & 0 & 1 & 1.52 \\
\hline g. Other profession & 9 & 8.18 & 18 & 27.27 \\
\hline \multicolumn{5}{|l|}{ 2. Future dreams of profession* } \\
\hline a. Nursing practitioner & 67 & 60.91 & 28 & 42.42 \\
\hline b. Academician/researcher & 9 & 8.18 & 1 & 1.52 \\
\hline c. Nursing lecturer & 34 & 30.91 & 14 & 21.21 \\
\hline d. Health officer & 36 & 32.73 & 22 & 33.33 \\
\hline e. Civil servant (administrative) & 56 & 50.91 & 49 & 74.24 \\
\hline f. Other profession & 21 & 19.09 & 10 & 15.15 \\
\hline g. Not decided yet & 6 & 5.45 & 2 & 3.03 \\
\hline \multicolumn{5}{|c|}{$\begin{array}{l}\text { The sum / amount of chosen future dreams of } \\
\text { profession: }\end{array}$} \\
\hline a. 0 & 5 & 4.55 & 3 & 4.55 \\
\hline b. 1 & 29 & 26.36 & 28 & 42.42 \\
\hline c. 2 & 42 & 38.18 & 18 & 27.27 \\
\hline d. 3 & 21 & 19.09 & 10 & 15.15 \\
\hline e. 4 & 11 & 10.00 & 7 & 10.61 \\
\hline f. 5 & 2 & 1.82 & 0 & 0 \\
\hline \multicolumn{5}{|l|}{ 3. Type of chosen nursing practitioner } \\
\hline a. Advanced nursing specialist & 12 & 10.91 & 4 & 6.06 \\
\hline b. Public health/community nurses & 26 & 23.64 & 13 & 19.70 \\
\hline c. Both above & 27 & 24.55 & 15 & 22.73 \\
\hline d. Can't choose any above & 45 & 40.91 & 34 & 51.52 \\
\hline \multicolumn{5}{|l|}{ 4. Nursing fields preference* } \\
\hline a. Medical nursing & 21 & 19.09 & 5 & 7.58 \\
\hline b. Surgical nursing & 34 & 30.91 & 13 & 19.70 \\
\hline c. Intensive nursing & 13 & 11.82 & 11 & 16.67 \\
\hline d. Emergency nursing & 34 & 30.91 & 12 & 18.18 \\
\hline e. Palliative nursing & 2 & 1.82 & 2 & 3.03 \\
\hline f. Maternity nursing & 5 & 4.55 & 1 & 1.52 \\
\hline g. Pediatric nursing & 38 & 34.55 & 8 & 12.12 \\
\hline h. Mental health nursing & 10 & 9.09 & 17 & 25.76 \\
\hline i. Community health nursing & 4 & 3.64 & 5 & 7.58 \\
\hline j. Family health nursing & 19 & 17.27 & 8 & 12.12 \\
\hline k. Gerontology nursing & 3 & 2.73 & 4 & 6.06 \\
\hline 1. Basic nursing & 16 & 14.55 & 0 & 0 \\
\hline m. Nursing management & 19 & 17.27 & 2 & 3.03 \\
\hline n. Nursing education & 6 & 5.45 & 3 & 4.55 \\
\hline \multicolumn{5}{|c|}{ The sum / amount of chosen nursing fields: } \\
\hline a. 0 & 27 & 24.55 & 34 & 51.52 \\
\hline b. 1 & 17 & 15.45 & 4 & 6.06 \\
\hline c. 2 & 26 & 23.64 & 11 & 16.67 \\
\hline d. 3 & 17 & 15.45 & 10 & 15.15 \\
\hline e. 4 & 14 & 12.73 & 2 & 3.03 \\
\hline f. 5 & 5 & 4.55 & 1 & 1.52 \\
\hline g. 6 & 2 & 1.82 & 1 & 1.52 \\
\hline h. 7 & 2 & 1.82 & 1 & 1.52 \\
\hline
\end{tabular}

*Respondents may choose more than one answer. 
Sari, N.P.W. | Career Choices among Nursing Students: Differences Between Freshmen ...

\section{DISCUSSION}

\section{Reasons for choosing nursing major}

Results showed that the majority of freshmen chose nursing major due to childhood dream (49.09\%), while interns had other reasons (37.88\%). Some occupations are narrated as a realisation of childhood dreams (Heggli, et al., 2013). A study towards young registered nurses showed that one of the reason to leave nursing profession and doing professional turnover was because nursing career had not been a childhood dream for them (Flinkman, et al., 2013). It could be predicted that if most freshmen in this study finally become a real nurse practitioner in the future then they will have low intention to leave nursing profession or doing professional turnover.

In the case of most interns in this study, the other reasons they expressed were mostly related to family influence, especially the parents. Family influence is one of the criteria for nursing students to choose nursing profession as their future career (Diomidous, 2012). A study towards 68 undergraduate nursing students in the second year of their program showed that family members in the healthcare profession were perceived to be great sources of both emotional and instrumental support (McLaughlin, et al., 2010). Although in this study most parents' profession are other than nursing or healthcare profession (94.32\% totally), but it seemed that they had a great trust in nursing profession, until then they "directed" their child to study nursing major in the university, being the greatest motivator $(81.82 \%$ totally), and a great role model (37.5\% totally). We could see how big is the public trust towards nursing profession in this study context. Even in the United States (US), in February 2019, nurses ranked "most trusted profession" for the $20^{\text {th }}$ consecutive year, especially related to ethical standard and honesty (Stone, 2019).

There were $6.25 \%$ respondents in total who already had a Bachelor degree from other major who chose to study about nursing as their second major, indicating that the opportunities nursing presented were also deemed influential. Another example, in the Southeastern US, the fastest growing university-based nursing programs are the accelerated programs of study for students who hold a baccalaureate degree in another discipline and desire to change careers. A study towards 66 second degree students in the Southeastern US showed that there were three themes of reasons why these students chose nursing as their second career, such as: what I bring to nursing, seeking satisfying work, and the missing piece (Raines, 2010).

Various studies have shown that the positive image of nursing in public attracts applicants (Beck, 2000; Rheaume et al., 2003; in Bolan \& Grainger, 2009). Most respondents were determined and committed to study about nursing, indicated by no experience of choosing other major ( $82.95 \%$ totally) and no working experience before entering the university $(86.93 \%$ totally). This happen potentially because of their personal reasons of choosing nursing major. Results showed that the second most popular reason in choosing nursing major turned out to be able to help others (26.14\% totally). This finding is supported by a study towards nursing freshmen in Sydney's urban university which showed that personal reasons dominate the reasons in choosing nursing major: the opportunity to help and care for others (Wilkes, et al., 2015).

\section{Career choices of nursing students}

In this study, most freshmen chose two career choice alternatives e.g. nurse practitioner and civil servant (38.18\%), but most interns were determined to choose only one alternative e.g. civil servant (42.42\%). This differences found potentially cause by the influence of grade differences. A study towards 429 students showed that in term of choosing career in health-related field, the grade differences between freshmen and senior students had more influence on the freshmen (Lockridge, 2000). It seemed that freshmen were more hesitant than interns in choosing their future career, while the interns seemed to be more optimistic. This possibly happened because the freshmen experienced more career decision difficulty compared to interns due to lack of 
Sari, N.P.W. | Career Choices among Nursing Students: Differences Between Freshmen ...

readiness related to younger age. In this study, freshmen were mostly aged 18-20 years old $(81.82 \%)$ while interns were mostly aged $21-23$ years old (87.88\%). A study towards 209 university students in America showed that younger respondents experienced lack of readiness more than senior students, so that they reported more career decision difficulties (Laveck, 2018). Sari \& Putra (2019) found that the lack of readiness found in nursing freshmen is mostly cause by the lack of information, especially about preferred career alternatives, career-related preferences, abilities and personality traits in the future.

Based on a study towards 304 university students in America, Gati, et al. (1996) found that the usual problems arise in the initial phase of study in the university experienced by freshmen are: 1) lack of motivation, 2) presents of doubts, 3) the existence of dysfunctional myths circulating in the community, and 4) lack of knowledge about the learning process in the college, in which all have contributions to the lack of individual readiness resulted in career-decision difficulty among freshmen. In contrary, career optimism in interns may be resulted from the high support of parents and lecturer or academic advisor in the initial phase, and high self-efficacy related to career decision making in the final phase of study in the university (Garcia, et al., 2015).

Another potential reason is because of the present of cultural values conflict related to Asian ethnic. In this study, most respondents are Balinese (59.66\% totally), a sub-group of Asian ethnic. A study towards 1,342 university students showed that conflict of cultural values correlated with higher career decision difficulties, in which cultural value orientation mediating the correlation between career expectation and career decision difficulty in Asian sub-group (especially Chinese) [Leung, et al., 2011).

Culture could influence individual career development and the process of career decision making (Mau, 2004; Tagay, 2014; in Laveck, 2018). A study towards 232 university students with various cultural background in America showed that Asian reported higher career decision difficulties compared to other ethnics (FeinsteinMessinger, 2007). Worldwide, Balinese is famous for their strong customs, traditions, and cultural values. When it comes to career decision making, most Balinese young adults are influenced by their parents/family opinion as most emotional and instrumental support for studying in the university come from them, especially in single respondents (76.7\% totally) who live with parents $(63.07 \%$ totally) in the rural area (46.02\% totally), whose mind is relatively conservative.

Results showed that there were two most popular career choices among nursing students, both in freshmen and interns, such as: nurse practitioner $(45.45 \%$ totally) and continuing education to be a Master/Specialist of Nursing (33.52\% totally). Profession of nurse practitioner attracts many nursing students potentially because of positive nursing image in the public. A study in Canada towards 213 nursing freshmen and 150 senior students showed that the majority had a positive image of nursing profession, but nursing orientation, nurse's role perspective, nursing education, political issues, and nursing value as a profession were differed significantly between groups (Grainger \& Bolan, 2006). Three years after, in 2009, the same authors in their other longitudinal study found that the students still had a positive image of nursing and this became significantly more positive as they progressed in the nursing program (Bolan \& Grainger, 2009). Other than nursing image, nursing orientation, perspective, education, politics, and professional values are potential influencing factors for deciding nursing career which unidentified in this study.

Diomidous (2012) stated that the suitability with personality type is being one of the criteria for nursing students to choose nurse practitioner as future profession. Results showed that most respondents were introverted individuals $(52.84 \%$ totally), melancholic ( $53.41 \%$ totally), and realistic (68.18\% totally). There is no specific study about personality type and its connection with nursing profession found yet. We could learn from one example from the field of information technology 
Sari, N.P.W. | Career Choices among Nursing Students: Differences Between Freshmen ...

(IT). A study towards 1,059 IT worker showed that introverted individuals was more suitable to work in this field (Lounsburry, et al., 2007). Therefore, there is a possibility that the career choice of study respondents associated with their personality type.

Diomidous (2012) also stated that the other criteria is the influence from friends. In this study, most respondents' daily association was with friends $(94.32 \%$ totally) whose profession is the same nursing students (classified as others: $90.91 \%$ totally), and they had one close person whose profession is nurse practitioner ( $60.23 \%$ totally). Other than family and teacher/lecturer, friends are considered as significant others too for nursing students which influence them to choose nursing career, because they provide support and being positive role nodel (McLaughlin, et al., 2010).

Most respondents in this study were unable to decide the type of nursing practitioner they wanted to be in the future ( $44.89 \%$ totally). It is usual to find there are many students struggle in making career decision while studying in the university in which transition phase happen; a shift from education period to the work world (Mau, 2004; in Laveck, 2018). The results of preliminary study showed that both nursing freshmen and interns experienced moderate level of career decision difficulty (Sari \& Putra, 2019); which make them similarly hesitant, especially when it comes to choose or decide the type of nursing practitioner they wanted to be in the future.

The career intention to be a nurse practitioner in most respondents was referred to civil servant, both in clinical or community work places $(59.66 \%$ totally). Being a civil servant in Indonesia is highly appreciated by the community, and it could be the familial/ parental expectation too, especially for those who live in the rural area and having relatively conservative mind. A study towards Asian young adults in America showed that parental expectation, parent-child relationship, and Asian cultural values influenced individual career development significantly (Sandhu, 2014). Another study towards 1,342 university students in China showed that parental expectation could predict career decision difficulty in their children
(Leung, et al., 2011). In the other hand, family expectation and cultural value could influence career prospect and individual career decision (Mani, 2008; in Ettigi, 2017). Ettigi (2017) found that family expectation was significantly correlated with career decision difficulty.

Another study towards 200 students showed that parental expectation towards their child's future career was significantly associated with socioeconomic status or social class (Wilson, 2011). In this study, most respondents live with their parents (63.07\% totally), whose social class is middle level (77.27\% totally). By being a civil servant, parents expect their child to have a secure job with stable monthly income and pension guaranteed with implication towards financial trust from the bank and various monetary agencies in Indonesia, so that the child can contribute positively to the family expenses or financial obligations. Other reason is the career ladder stated by the gevernment is fixed for the civil servant, according to law/decree of the Ministry of Labor or Ministry of Internal Affairs, giving the parents another secure feeling regarding their child's future career.

Being a civil servant in Indonesia is not only giving the chance of getting financial security or prospective career ladder for some individuals. Other than that, the opportunities to be involved in governmental issues or concerns, as well as policy development and implementation in various level of govermentary (local, state/province, or national level), including the opportunity to travel around the nation and abroad for governmental mission, is undeniable and really being a great temptation for many individuals, especially the young generation. But the essential thing is, by having a selfdetermination to be a civil servant in the future, like the majority in this study context, the profession of being a nurse practitioner is not guaranteed. This happened because by being a civil servant, the work place will be various; not only being a nurse practitioner in clinical or community context, but the nursing graduates could be an administrative officer in the Ministry of Health or another governmental bodies. Therefore, the career of nurse practitioner is still at stake. 
Sari, N.P.W. | Career Choices among Nursing Students: Differences Between Freshmen ...

In case of being a nurse practitioner in the future, results showed that the most popular nursing fields were pediatric nursing in freshmen and psychiatric nursing in interns $(34.55 \%$ and $25.76 \%$ respectively). This finding was supported by a longitudinal study towards nursing students in Australia (2005-2007) which showed that the field of paediatric nursing was really popular among freshmen and two years after most of them preferred psychiatric nursing field (McCann, et al., 2010). A qualitative study towards Dutch nursing students showed that nursing freshmen have stereotype, mostly negative perceptions of psychiatric patients and mental health care which strongly influence their future career choices (Hoekstra, et al., 2010). Results of systematic review showed that nursing students will have a more positive attitude towards mental health care when they had received more hours of theoretical preparations and taking longer clinical placements (Happell \& Gaskin, 2013). The changes happened after being an intern in this study context possibly due to the clinical placements which allowed students exposures towards psychiatric patients, so that their stereotype changes and forming a more positive perception about psychiatric patients and mental health care.

Another supportive study was conducted by Kloster, et al., (2007) in Norwegia towards 620 freshmen which showed that the field of paediatric nursing was the most popular field among freshmen, while the other 386 senior students ( $3^{\text {rd }}$ grade) mostly preferred psychiatric nursing field. This change occurs because senior students already have sufficient clinical practice experience and feel challenged professionally, so this is what gives them a reason to choose the preferred nursing field.

This finding is also potentially influenced by gender. Gender could explain the high variance in individual career expectation, apart from the knowledge disciplin or even the academic achievement (Schweitzer, et al., 2011). There were $23.86 \%$ (in total) male respondents in this study. A study about men in nursing $(\mathrm{n}=367)$ showed that male nurses considered certain fields of nursing (e.g., administration, emergency, or intensive care) because they thought it would be more congruent with the male sex role than other fields (e.g., general medical, outpatient, or obstetrical nursing) [Egeland \& Brown, 1989]. But, most respondents were female in this study context (76.14\% totally). It is very common to find more female students in nursing major worldwide. Feminine occupations, e.g. nurse, were under-represented among the perceived high status jobs (Teig \& Susskind, 2008). Related to personality traits, a study towards 36 students showed that after being a real professional, females are more positive and optimistic in self confidence to develop their career (Bennett, et al., 1999). Another study towards 23,413 students in Canada in contrary found that females had lower salary expectation, expecting longer time of career promotion; females' career priority is mostly related to low-salary profession (Schweitzer, et al., 2011). In some part of Indonesia, nursing profession is related to low salary, especially in rural area or private agencies.

There are psychological limitations in both men and women if they decide on a career as a nurse. A study towards freshmen in the United Kingdom showed that there are certain areas of specialization that are popular among male and female nursing students that relate to their perceptions of the nurse profession that is appropriate for their sex (Muldoon \& Reilly, 2003). There is an influence of gender and role identity according to sex which also influences the choice of the field of nursing specialization to be pursued if a nursing student has chosen a career as a nurse practitioner.

Currie (2006) explains there are various competencies needed by pediatric nurses related to uncertainty in pediatric nursing care, such as: patient safety, competency documents, imagination, advanced decision making, accurate knowledge of physical and psychological development changes of children aged between 5 18 years old, accurate referral to X-ray, and good pediatric emergency care. As for pediatric care in emergency unit, there are some other specific competencies needed by emergency nurses. A qualitative study towards 13 nurses in primary care 
Sari, N.P.W. | Career Choices among Nursing Students: Differences Between Freshmen ...

setting in Brazil showed that there are five skills needed to promote child health in the community, such as: to catalyze change, assessment, planning, implementation and partnerships (Costa, et al., 2016). Nursing institutions are recommended to emphasize the curriculum outcome into the aforementioned competencies, especially in first year nursing courses, as many freshmen wish to work in paediatric ward.

Results of an integrative review of literature showed that the nursing competencies needed in mental health promotion are monitoring and ensuring the quality of health care practice, management of patient health/illness status, cultural competence, managing and negotiating health care delivery systems, the nurse practitioner-patient relationship (Aguiar, et al., 2012). A study towards 844 psychiatric nurses who were regularly dealing with patients of psychiatric and substance abuse behaviors showed that nurses need competencies of crisis communication and de-escalation techniques (Rutledge, et al., 2013). Nursing institutions are recommended to emphasize the curriculum outcome into the aforementioned competencies, especially in third year nursing courses, as many senior students wish to work in psychiatric ward or mental health hospital.

Results also showed that in $2^{\text {nd }}$ place, the fields of surgical and emergency nursing were the two fields which similarly popular in nursing freshmen and interns. The interest towards surgical nursing means that the respondents want to work in the operating theatre, whether being a scrub nurse or anesthetic nurse; while the interest towards emergency nursing means that the respondents want to work in the emergency room. A qualitative study towards 27 operating theatre nurrses in Queensland showed that there were three themes found related to competencies needed in

\section{REFERENCES}

Aguiar, M. I. F., Lima, H. P., Braga, V. A. B., Aquino, P. S., Pinheiro, A. K. B., \& Ximenes, L. B. (2012). Nurse competencies for health promotion in the mental health context. Acta operating theatre: 1) knowledge: coalescence of theoretical, practical, situational and aesthetic knowledge within a technocratic environment, 2) teamwork and communication: the importance of highly developed communication skills among teams of divergent personalities and situations, and $3)$ the ability to coordinate and manage: managing and coordinating the flow of the list (Gillespie, et al., 2009). Another study towards 710 emergency nurses in Iran showed that there are five domains of competencies needed in emergency room: 1) communication, 2) professional maturity, 3) personality characteristics, 4) scientific and technical capabilities, and 5) basic clinical skills (Ghanbari, et al., 2017). Nursing institutions are recommended to emphasize the curriculum outcome into the aforementioned competencies.

\section{CONCLUSION}

This study results indicate that the profession of nurse practitioner is popular among nursing freshmen and interns, but their most preference is being a civil servant in the future, whether being a nurse practitioner or administrative officer are in personal negotiation. This condition made the profession of nurse practitioner in the future still at stake. Generally, freshmen are more hesitant than interns in deciding their future career, but both groups of students are hesitant in choosing the type of nursing field they want to pursue after work. Superficially, paediatric and psychiatric nursing field are in the top rank among freshmen and interns respectively, while surgical and emergency nursing are in the $2^{\text {nd }}$ rank in both groups.

\section{ACKNOWLEDGEMENT}

This study was funded and supported for publication by Faculty of Nursing, Widya Mandala Catholic University Surabaya.

Paulista de Enfermagem, 25(2), DOI: http://dx.doi.org/10.1590/S010321002012000900025.

Bolan, C., \& Grainger, P. (2009). Students in the BN program - Do their perceptions change? Nurse Education Today, 29(7), 775-779. 
Sari, N.P.W. | Career Choices among Nursing Students: Differences Between Freshmen ...

Costa, A. C. P. J., Carvalho, Q. G. S., Lima, S. C. D., Ximenes, L. B., Pinheiro, A. K. B., Castro, R. C. M., Aquino, P. S., \& Vieira, N. F. C. (2016). Nursing competencies for child health promotion. Journal of Nursing Education and Practice, 6(4), 130-135.

Diomidous, M., Mpizopoulou, Z., Kalokairinou, A., Mprokalaki, I., Zikos, D., \& Katostaras, T. (2012). Descriptive Study of Nursing Students' Motives to Choose Nursing as a Career. Retrieved from: journal-ene.gr/wpcontent/uploads/2013/07/descriptive_study_n ursing_students.pdf

Ettigi, S. (2017). The role of family expectations and internalized model minority on career choices of south Asian American college students. Dissertation. ProQuest Dissertations Publishing, 10619003.

Flinkman, M., Isopahkala-Bouret, U., \& Salantera, S. (2013). Young registered nurses' intention to leave the profession and professional turnover in early career: a qualitative case study. International Scholarly Research Notices, vol. 2013, 916061, DOI: http://dx.doi.org/10.1155/2013/916061.

Garcia, P. R. J. M., Restubog, S. L. D., Bordia, P., Bordia, S., \& Roxas, R. E. O. (2015). Career optimism: the roles of contextual support and career decision-making self-efficacy, Journal of Vocational Behavior, 88, 10-18.

Gati, I., Krausz, M., \& Osipow, S. H. (1996). A taxonomy of difficulties in career decision making. Journal of Counseling Psychology, 43(4), 510-526.

Ghanbari, A., Hasandoost, F., Lyili, E. K., Khomeiran, R. T., \& Momeni, M. (2017). Assessing emergency nurses' clinical competency: an exploratory factor analysis study. Iran J Nurs Midwivery Res., 22(4), 280-286.

Gillespie, B. M., Chaboyer, W., Wallis, M., Chang, H-Y. A., \& Werder, H. (2009). Operating theatre nurses' perceptions of competence: a focus group study. Journal of Advanced Nursing, 65(5), 1019-1028.

Grainger, P., \& Bolan, C. (2006). Perceptions of nursing as a career choice of students in the Baccalaureate nursing program. Nurse Education Today, 26(1), 38-44.
Gunawan, J., \& Aungsuroch, Y. (2015). ASEAN mutual recognition arrangement for Indonesia nurses: is it a promise? International Journal of Community Medicine and Public Health, 2(2), 77-80.

Haase, H. (2011). Career Choice Motivations of University Students. International Journal of Business Administration, 2(1). Retrieved from: https://doi.org/10.5430/ijba.v2n1p2

Happell, B., \& Gaskin, C. J. (2013). The attitudes of undergraduate nursing students towards mental health nursing: a systematic review. Journal of Clinical Nursing, 22(1-2), 148158.

Heggli, G., Haukanes, H., \& Tjomsland, M. (2013). Fearing the future? Young people envisioning their working lives in the Czech Republic, Norway and Tunisia. Journal of Youth Studies, 16(7), 916-931.

Hoekstra, H. J., vanMeijel, B. B., \& van derHooftLeemans, T. G. (2010). A nursing career in mental health care: choices and motives of nursing students. Nurse Education Today, 30(1), 4-8.

Jirwe, M., \& Rudman, A. (2012). Why choose a career in nursing? JAN, 68(7), 1615-1623.

Kloster, T., Hoie, M., \& Skar, R. (2007). Nursing students' career preferences: a Norwegian study. JAN, 59(2), 155-162.

Kunnen, E. S. (2013). The Effects of Career Choice Guidance on Identity Development. Retrieved from: http://dx.doi.org/10.1155/2013/901718

Laveck, L. M. (2018). Career decision-making difficulties among student veterans. ProQuest Dissertations Publishing, 11005236.

Leung, A., Hou, Z. J., Gati, I., \& Li, X. (2011). Effects of parental expectations and culturalvalues orientation on career decision-making difficulties of Chinese University students. Journal of Vocational Behavior, 78(1), 11-20.

Lockridge, E. J. K. (2000). Career aspirations and expectations of selected Texas high school students as they relate to demographic characteristics and occupational projections. ProQuest Dissertations Publishing, 9980180. 
Sari, N.P.W. | Career Choices among Nursing Students: Differences Between Freshmen ...

Lounsbury, J. W., Moffitt, L., Gibson L. W., Drost, A. W., \& Stevens, M. (2007). An investigation of personality traits in relation to job and career satisfaction of information technology professionals. Journal of Information Technology, 22, 174-183.

Magno, P. (2017). 4 Career Alternatives, Choices for a Nurse (in Bahasa Indonesia). Retrieved from: https://today.mims.com/4-alternatifkarir--pilihan-untuk-seorang-perawat

McCann, T. V., Clark, E., \& Lu, S. (2010). Bachelor of Nursing students career choices: a three-year longitudinal study. Nurse Education Today, 30(1), 31-36.

McLaughlin, K., Moutray, M., \& Moore, C. (2010). Career motivation in nursing students and the perceived influence of significant others. Journal of Advanced Nursing, 66(2), 404412.

Muldoon, O. T., \& Reilly, J. (2003). Career choice in nursing students: gendered constructs as psychological barriers. JAN, 43(1), 93-100.

Price, S. L. (2011). The Experience of Choosing Nursing as a Career: Narratives from Millennial Nurses. Retrieved from: https://tspace.library.utoronto.ca/bitstream/18 07/31905/3/Price_Sheri_L_201111_PhD_the sis.pdf

Raines, D. A. (2010). What Attracts Second Degree Students to a Career In Nursing? OJIN: The Online Journal of Issues in Nursing, 16(1), DOI: 10.3912/OJIN.Vol16No01PPT03.

Rutledge, D. N., Wickman, M. E., Cacciata, M., Winokur, E. J., Loucks, J., \& Drake, D. (2013). Hospital staff nurse perceptions of competency to care for patients with psychiatric or behavioral health concerns. Journal for Nurses in Professional Development, 29(5), 255-262.

Sandhu, G. (2014). The infuence of family and cultural values on the career development of
Asian Americans. ProQuest Dissertations Publishing, 10034392.

Sari, N. P. W. P. \& Putra, M. M. (2019). Comparison of career decision difficulties between nursing freshmen and interns. Unpublished Work: Manuscript of International Journal of Public Health Sciences (IJPHS).

Schutt, D.A. (2008). How To Plan And Develop A Career Center. New York: Ferguson Publishing.

Schweitzer, L., Ng, E., Lyons, S., \& Kuron, L. (2011). Exploring the career pipeline: gender differences in pre-career expectations. Relations Industrielles, 66(3), 422-444.

Stone, A. (2019). Nurses ranked 'Most Trusted Profession' in 2019. ONS Voice: News, Views, and Advocacy from The Oncology Nursing Society. Retrieved from: https://voice.ons.org/advocacy/nursesranked-most-trusted-profession-in-2019

Takeda, Y., Kunimasa, M., Snell, L., Otaki, J., Takahashi, M., \& Kai, I. (2013). Characteristic Profiles Among Students and Junior Doctors with Specific Career Preferences. BMC Med Educ (13), 125.

Teig, S., \& Susskind, J. E. (2008). Truck driver or nurse? The impact of gender roles and occupational status on children's occupational preferences. Sex Roles, 58 (11-12), 848-863.

Wilkes, L., Cowin, L., \& Johnson, M. (2015). The reasons students choose to undertake a nursing degree. Collegian, 22(3), 259-265.

Wilson, S. L. (2011). Direct and indirect effects of social class on career expectations and likelihood of compromise in an adolescent sample. ProQuest Dissertations Publishing, 3498446.

World Health Organization (WHO). (2006). Working Together for Health: The World Health Report 2006. Geneva: WHO. 